\title{
Risk management method for construction projects using a value-based approach
}

\author{
Seek Ali Mohamed Abdulsalam \\ University "KROK”, Kyiv, Ukraine \\ Corresponding author. E-mail: dimi7928@gmail.com
}

Paper received 22.05.20; Accepted for publication 15.06.20.

\section{https://doi.org/10.31174/SEND-HS2020-232VIII40-08}

\begin{abstract}
The article presents a risk management method for construction projects that are implemented using a value-based approach. Existing risk management tools are considered and analyzed. The necessity of taking into account the risks brought to the project by its stakeholders in the paradigm of value-oriented management is shown. The structure of the method and the sequence of steps for assessing and working with the risks of construction projects with value-oriented management are presented.
\end{abstract}

Keywords: risk management method, value-oriented approach, stakeholder management, risks of construction projects.

Introduction. The development of risk management tools in the construction project management industry requires the isolation, limitation and concretization of basic terminology, as well as methods and tools, from the overall risk management regulation.

Review of publications on the topic. Among the significant variety of standards and methods for risk management [1 - 7] note the following:

- standard of the Federation of European Risk Management Associations "FERMA" [1, 2];

- standard "COCO II" [1, 2];

- South African standard "KING II" [1, 2].

- standard ISO 31000:2009 "Risk Management - Principles and Guidelines" [3];

- standard IEC/FDIS 31010:2009 "Risk Management Risk Assessment Techniques" [4];

- standard ISO 73: 2009 "Risk management. Terms and definitions" [5].

The general PMBOK standard of the 6th edition [8] presents an extended concept of risk management in the project, and provides the following basic definitions.

Thus [8, p. 397] introduces the concepts of individual and aggregate project risk. In the first case, “... it is an uncertain event or condition, the occurrence of which has a positive or negative effect on one or more project objectives". The aggregate risk is positioned as the impact of uncertainty on the project as a whole, “...as a consequence of variations in project results, both positive and negative, on stakeholders".

In addition, the concept of "non-event risk" of two types is introduced [8, p. 398]:

- the risk of variability when there is uncertainty regarding certain key characteristics of an event, operation or decision foreseen by the plan;

- the risk of ambiguity when there is uncertainty about what may happen in the future. The areas of the project in which incomplete knowledge may affect the ability to achieve the objectives of the project include: elements of requirements or technical solutions; future regulatory development; system complexity inherent in the project.

The author [9] notes that "... the terms "uncertainty", "decision-making", "risk" and "danger" should constitute an integral terminological system".

In article [9], the author gives the following definitions to the indicated terms: "Uncertainty is a state of a person, determined by his system of knowledge in a specific situation of an objectively uncertain environment regarding the impossibility / possibility of deciding on further activities in case of incomplete and unclear perception of the situation, his insufficient awareness and uncertainty in necessary actions associated with future events, their impact on activities and implications for expected values (planned result)".

"Risk is a state of activity of the management object, which is realized in the conditions of uncertainty when manifestation of events (quantitatively taken into account and not taken into account at decision-making about activity) which can lead primarily to negative deviations from achievement of expected value (planned result) is possible".

The authors [10, p. 137-138] determine the uncertainty in the construction project and its risks, as follows. Uncertainty is ".. incompleteness or incorrectness of information about the conditions of the project, including information about possible costs and the corresponding results of the actual implementation of the project".

The authors associate uncertainty with the external environment (economic, political, social, etc.) and the set of variables that must be taken into account in the process of project development.

The reasons for uncertainty in construction projects are indicated [10]:

- spontaneity of natural processes and phenomena, natural disasters;

- coincidence, when under similar conditions, the same event occurs differently as a result of many socioeconomic and technological processes;

- presence of conflicting tendencies and interests;

- incompleteness, lack of information about the object, process, phenomenon;

- limited information on the rhythm of providing material, financial, labor and other resources in the process of project implementation.

Project risks are comprehended [10] as an action in the decision-making process on the feasibility of development and implementation of the project to achieve the aim, taking into account possible changes in the conditions of its implementation, the occurrence of adverse circumstances and related consequences of losses, damages.

The authors of [10] measure the magnitude of the risks "... by the probability of the occurrence of a particular event, which can lead to losses in the process of project implementation. Probability is determined by statistical or subjective methods. According to the sources of occur- 
rence, the risks are classified as political, internal and force majeure".

For construction projects, the authors of [10] additionally identify the risks associated with: mistakes in the design and estimate documentation; insufficient qualification of specialists; delivery delays; low quality of component materials, structures and products; breaks in contracts, etc.

Professor Bilokin A.I. in [11] identifies the following risks of construction / development projects:

- long stage of approval of project documentation;

- making changes to the design assignment by the customer;

- making changes to design decisions by the customer;

- lack of design options by designers;

- lack of designers' certain experience in designing modern multifunctional complexes, taking into account modern energy-saving technologies in the operation of a real property;

- lack of qualified designers for individual engineering sections of the project;

- coordination and interaction between the customer, management company, designers, marketers, consultants, technologists and other project participants;

- cost-effectiveness of design decisions;

- quality of project documentation;

- the issue of connecting the property to utilities;

- lack of experience in professional liability insurance for architects and designers;

- the difficulty of communicating with foreign designers if they are in the project.

Evidently, the list contains risks associated with the influence of customers, but they are not deciphered, presented by one category - "customer", and generally there are no risks in terms of satisfaction of individual customers and contradictions between them.

The objectives of project risk management are $[8, \mathrm{p}$. $395]$ to increase the probability of occurrence and / or impact of positive risks and reduce the probability of occurrence and / or impact of negative risks in order to maximize the probability of successful project completion. Project risk management according to the 6th version of the PMBOK standard [8, p. 395] includes the processes of: risk management planning, identification, analysis, response planning, response implementation, risk monitoring in the project.

The PMBOK standard in construction $[12$, p. 23] defines risk as the possibility / probability of positive and negative events that occur in the design and construction process, between the interests of various project stakeholders and the project context. This applies to stakeholders, international law or international financial institutions (for example, projects developed as part of joint construction projects, public-private partnerships or international construction projects).

Risk response planning in construction projects is a more complex process due to the involvement of subcontractors.

Monitoring and control of risks within a group of monitoring and control processes should be developed proactively and continuously throughout the project life cycle, especially for large construction projects or projects in a dynamic environment.
Project risk management includes processes for risk management planning, identification, analysis, response planning and project control. Project risk management is essential for successful project management and should be applied throughout the project life cycle. The main objectives of project risk management are to increase the probability and impact of positive events or opportunities while reducing the probability and impact of negative events or threats to the project [12, p. 99]. Project risk management helps stakeholders by providing greater confidence in project results, reducing risk exposure, defining project strategies for bidding and negotiating contracts, and estimating the cost and schedule of contingency reserves.

Common factors for the construction industry, which constantly give rise to various uncertain situations in construction projects, are presented in [12, p. 99]: long duration and aggressive schedules; environmental change and the dynamic nature of the workplace; complex technical processes; open places that are highly exposed to the environment; unskilled labor; shortage of materials; various organizations actively involved in the construction project with different goals, interests and expectations; various works of public interest; change in prices for materials; regulatory requirements.

Appendix X3 [12, p. 189] describes the most common causes of risks in construction projects.

Risk management is a critical component of construction project management, especially in a turbulent design environment. In particular, in Ukraine, symptoms of low controllability of construction projects are often observed: a significant number of objects are put into operation in excess of the planned period, budget etc. In addition, there are risks associated with improving the project management system itself [13].

The analysis of the subject area and literary sources showed that there are contradictions in project management in construction projects that are managed using a value-oriented approach. This contradiction lies in the plane of risk management [14]. Based on the contradiction, a problem was formulated, for the solution of which a conceptual risk management model [15] and a mathematical model [16] were proposed and developed.

The aim of this study is to develop an action algorithm for project managers and members of risk management teams of construction projects based on a valueoriented approach.

Materials and methods. This algorithm was formed, generalized and tested by the author, as a result of which a method of risk management in construction projects (CP) based on a value-oriented approach (VOA) was proposed.

The method was developed taking into account the proposed conceptual [15] and mathematical model [16], as well as on the basis of the information model PMBOK Construction [12] "Risk Management Planning". It contains "Inputs", "Tools and Methods" and "Outputs". In order to use this model for risk management of the CPVOA, the "input data" decomposition was performed [17]:

- Project charter. The level of safety and reliability of the building (class of responsibility) is determined by the ratio with the number of people at the facility [18];

- Policy. The risk management policy of a construction 
company should be based on compliance with the requirements of construction norms and rules;

- Certain roles and responsibilities / Responsibility of stakeholders. In particular, the project manager, production and technical manager, project and technical manager, risk manager, special project group of the VOA ensure the safety and reliability of the construction project, work with stakeholders, identify their expectations and values [17];

- Profile. The social profile of stakeholders of the construction project and determination of their mobility. For example, the social categories of apartment building users are children, youth, adults, the disabled, etc. [15];

- archived risk management plan for CPVOA implemented construction projects;

- The breakdown structure including "Lighting, video surveillance of the territory", "fire safety", "alarm / call buttons", "visible and clear signs / indicators", "barrierfree escape routes", "ramps for the disabled and wheelchairs", etc..should be consistent with the expectations of the main stakeholders of the project;

- The terms of the contract must include a guarantee and, if possible, an agreed consolidated opinion of stakeholders.

It is proposed to supplement the Planning Meetings ("Tools and Methods" module) with the following components: audit of stakeholder needs regarding the safety and ease of operation of the constructed building; expert assessment of the reliability of project decisions, fire safety, universal design of the building and the surrounding area [17].

The structure of the risk management method of CPVOA is shown in Fig. 1.

The business process "Risk management of a construction project based on a value-oriented approach" begins with how the vision of the project product will be formed by the customer (block 1, further B1). It is assumed that the project team has already been formed by this time and the development of project documentation begins according to the PMBOK (B2) methodology, or another corporate project management methodology, which is adopted by the project-oriented construction company POSK.The author recommends to create a special project team for the VOA, which will carry out all the tasks and processes identified in this method.

Results and discussion. Next, we present the sequence of actions in the form of steps.

Step 1 consists of two parallel processes that require various resources. Note that the parallel execution of processes in this method, assumes the availability of various resources for their implementation.

The first one is B 3.1, which the technology of construction works is being developed in.

The second process by which the special group of VOA (note that depending on the scale of the project it can be one person or a group) identifies project stakeholders (B 3.2), compiles their ranked list, communicates with them by available means based on the improved information model PMBOK Construction "Risk Management Planning" [17], described above.

Step 2 formalizes the values for each stakeholder or group of stakeholders (B 4.2) and in parallel forms the technological model of the project (B 4.1). Note that over time, these processes can have various durations and are not expected to end synchronously.

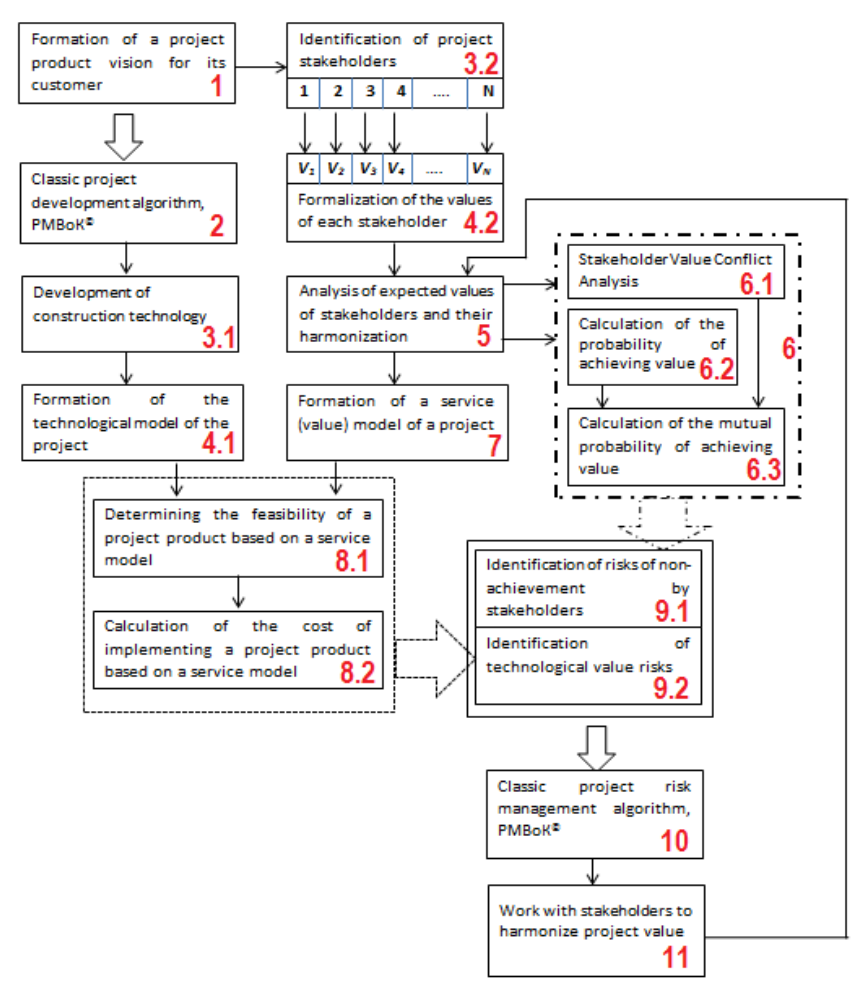

Fig.1. Structure of the risk management method for CPVOA

Step 3. After formalizing the expected values of all stakeholders, their analysis is carried out in order to harmonize the project as a whole [19] and values, in particular, the formation of a single vector that will not destroy the project, but will add a new additional value component. The results of the analysis from block 5, serve as input processes for the following two processes: analysis of the conflict of values among the project stakeholders (Block 6) and formation of the service model of the project (Block 7).

Step 4. Formally, the analysis of the conflict of values of the project stakeholders can be carried out on the basis of the method of pairwise comparisons, or by the expert method (B 6.1).

Stakeholders' expectations are identified that are antagonistic to each other. An accessibility analysis of value for each stakeholder is carried out, i.e., the probability is determined whether or not the stakeholder gains the expected value. The reasons for "non-achievement" can be very different, only the outcome is analyzed - whether or not the stakeholder will receive value and be satisfied with it (B 6.2).

The next block (B 6.3) examines the mutual influence of stakeholders on each other, the active influence of one stakeholder on the process of achieving value by another stakeholder. That is, the point is that the so-called mutual probability of reaching the $i$-th stakeholder of its value, depending on the impact on it $\mathrm{i}+1$ st stakeholder.

Step 5. In parallel with B6, B7 is executed - a service model of the project is being formed.

Note that at this interval stage, three parallel processes were completed, as a result of which the following was formed:

- technological model of the project (B 4.1) (this model 
meets the expectations of the customer / investor, taking into account the technological features of construction). This model is based on the recommendations of the PMBOK [8], or any other project management methodology adopted by the $\mathrm{CC}$;

- project service model (B 7) (this model meets the expectations of stakeholders, all or "selected" with no regard to the technological features of construction). This model is based on the recommendations developed by the authors of the model and presented in [20, 21];

- analysis of the value conflict of stakeholders, i.e. the "anti-project" model has been formed, which is unattainable (B 6). The analysis is based on the author's developments presented in $[15,16]$.

Step 6. Further, it is necessary to compare the results obtained with each other, make a decision and choose a development path [22]. As it is a question of use of VOA, the accepted decision should be aimed at developing such a project model that will satisfy as much as possible: the customer / investor and significant stakeholders, taking into account the strategic development goals of POSC in the conditions of the risks of the "anti-project".

Block 8 (B8) analyzes the feasibility of the service model of the project (B 8.1) by comparing the technological and service model of the project, and also calculates the cost of these changes in monetary, technological, resource and image senses. The final (one of the alternative) version of the project is specified and approved by the customer / investor, taking into account the risks of the VOA, which is developed in block B9. Note that this final version of the project is subject to implementation (execution).

Step 7. The processes of block 9 (B9) are conditionally divided into identifying risks that significant project stakeholders will receive or generate (B 9.1) and identifying risks that POSK will receive (customer / investor / project product manager) (B 9.2). Note that in both cases, the risks entail both material (financial) consequences / losses, and image ones. It is known that last ones can also be recalculated into financial losses, however, in this work, we intentionally separate them into a separate group.

Step 8. Upon completion of the processes of block 9, i.e. the risks are identified by the CPVOA, then in B 10 the risk management procedure is initiated by $\mathrm{PMBOK}$, or any other risk management methodology adopted in the POSK. The proposed difference from the standard procedure is the supplement of block 11 (B 11) to the processes presented in the PMBOK: "Risk Response Planning" and "Risk Response Implementation". The supplement is related to the used VOA, namely, work with stakeholders to harmonize the project, which in turn will reduce the risks of structural imbalance and the consequences from them.

Therefore, the output B11 is directed to the input B5, where the expected values are analyzed and their primary harmonization took place.

At this point, the presented risk management method for construction projects using VOA is completed. Risks are identified, quantitatively and qualitatively analyzed, their influence on the project value is determined, measures to reduce risks are proposed through harmonization of the project values.

It should also be noted that the developed method should be used both at the planning stage of the project and at the stage of its implementation, in order to monitor previously identified risks and identify new ones.

\section{REFERENCES}

1. Kotlobovskiy I. B., Shestakov D. A. Razvitiye standartizatsii v oblasti riskami [Development of standardization in the field of risk management]. Available at: http://www.finanal.ru/007/razvitie-standartizatsii-v-oblastiupravleniya-riskami.

2. Donets O.M., Savelieva T. V., Uretska Yu. I. Vukorystannia mizhnarodnykh standartiv $v$ upravlinni ryzykamy [Use of international standards in risk management]. Upravlinnia rozvytkom skladnukh system [Management of development of complex systems]. 2011, no. 6, pp. 36-42.

3. International standard Risk management - Principles and guidelines ISO 31000:2009(E). Switzerland, ISO copyright office, 2009. $36 \mathrm{p}$.

4. International standard Risk Management - Risk assessment techniques IEC/FDIS 31010:2009€. International Electrotechnical Commission, 2009. $92 \mathrm{p}$.

5. ISO GUIDE 73:2009 (E/F). Risk management - Vocabulary. 1st ed. 15 p. Available at: dvbi.ru>risk_management/library/tabid...ISO...73-2009....

6. ISO/IEC 31010:2009. Gosudarstvennyy standart respubliki Belarus [State standard of the Republic of Belarus]. Menedzhment riska. Metodiki otsenki riska [Risk management.Risk assessment techniques]. 79 p. Available at: tnpa.by>Проекты ТНПА〉... ISO IEC 31010 txt.pdf.

7. OKS 03.100.01. Natsionalnyy standart RF. Menedzhment riska. Printsipy i rukovodstvo [National standard of the Russian Federation. Risk management. Principles and Guidance]. Available at: http://www.nado-v-sro.ru/importantlaws/256/gost-r-iso-31000-2010/.

8. A Guide to the Project Management Body of Knowledge (PMBOK® Guide). Six Edition. USA. PMI Publ., 2017. 574 p.

9. Rach D. V. Upravlinnia nevyznachenistiu ta ryzykamy $v$ proekti: terminolohichna osnova [Uncertainty and risk management in the project: terminological basis]. Upravlinnia proektamy ta rozvytok vyrobnytstva [Project Management and Production Development]. 2013, no. 3(47), pp. 146-164. Available at: http://www.pmdp.org.ua/

10. Pshinko A. N., Radkevich A. V., Dadiverina L. N. Upravlenniye stroitelnymi proyektami: uchebnoye posobiye [Construction project management: a textbook]. Dnepr, 2017. 205 p.

11. Bilokon A. I. Orhanizatsiini aspekty pidhotovky proektiv developmentu [Organizational aspects of the preparation and implementation of development projects]. Upravlinnia proektamy ta rozvytok vyrobnytstva [Project Management and Production Development]. 2008, no. 2(26), pp 50-56.

12. Construction extension to the PMBOK ${ }^{\circledR}$ Guide. Project Management Institute, 2016. 215 p.

13. Fesenko T. H., Mohamed Abdulsalam Seek Ali. Ryzykmenedzhment $v$ konteksti modeli zrilosti upravlinnia budivelnymy proekramy [Risk management in the context of the maturity model of construction project management]. Upravlinnia proektamy u rozvytku suspilstva [Project Management in Society Development]. Kyiv, KNUBA Publ., 2018, pp. $217-$ 220.

14. Seek Ali Mohamed, Danchenko Olena. Analysis of sources of risk of construction projects in the plane of value-based management. Program, Portfolio Management. P3M-2019: The Proceedings of the International Research Conference. Book 2. Odesa, 2019, pp. 52-55. 
15. Seek Ali Mohamed Abdulsalam. Conceptual model for risk management of construction projects based on value-based approach. Upravlinnia proektamy ta rozvytok vyrobnytstva [Project Management and Production Development]. 2019. no. 3(71).

16. Seek Ali Mohamed Abdulsalam, Bielova Olena Ihorivna. Mathematical model of risk's evaluation in value-oriented approach for construction projects management. Upravlinnia proektamy ta rozvytok vyrobnytstva [Project Management and Production Development]. 2019, no. 4(72).

17. DBN B 1.2-14:2018. Derzhavni budivelni normy. Zahalni pryntsypy zapezpechnnia nadiinosti ta konstruktyvnoi bezpeky budivel $i$ sporud [State building codes. General principles for ensuring the reliability and structural safety of buildings and structures]. Kyiv, Minrehion Ukrainy Publ., 2018. 36 p.

18. Fesenko T., Mohamed Addulsalam Seek Ali "Safety" in the construction project as a process constant of risk management planning. Tezy dopovidei XVI mizhnarodnoi konferentsii " $U p$ ravlinnia proektamy u rozvytku suspilstva" [Proc. of the $15^{\text {th }}$ Int. Conf, Project Management and Production Development]. Kyiv, 2019, pp. 22-23.

19. Teslenko P.A. Harmonious project management. Harmonious development of systems is the third way of mankind: A collective monograph based on the proceedings of the 1st International Congress, Odessa, October 8-10, 2011. Ed. E.M.
Soroko, T.I. Egorova-Gudkova. Odessa: Institute of Creative Technologies, 2011, pp. 375 - 380.

20. Rach V. A., Mohammad Alatum. Strukturizatsiya skhematicheskoy, sistemnoy $i$ servisnoy modeley proyekta $c$ pozitsiy bazovykh polozheniy triadnoy paradigmy upravleniya proyektamy [Structuring of schematic, system and service models of the project from the standpoint of the basic provisions of the triad project management paradigm] Upravlinnia proektamy ta rozvytok vyrobnytstva [Project Management and Production Development]. 2011, no. 3(39), pp. 136-145.

21. Medvedieva E. Value-oriented collaboration management in projects: methodological bases. Thesis on competition for scientific degree of a doctor of technical sciences. Project and program management. Kyiv national university of construction and architecture, 2013. $44 \mathrm{p}$.

22. Teslenko P. A., Gogunskiy V. D. Trayektoriya razvitiya proyekta kak organizatsionno-tekhnicheskoy sistemy $v$ mnogomernom prostranstve peremennykh [The trajectory of project development as an organizational and technical system in the multidimensional space of variables]. Tezy dopovidei VI mizhnarodnoi konferentsii "Upravlinnia proektamy $u$ rozvytku suspilstva" [Proc. of the $6^{\text {th }}$ Int. Conf, Project Management and Production Development]. Kyiv, 2009, pp. 188189. 